\title{
WHAT E-COMPETENT PARENTS EXPECT FROM BOARDING SCHOOL?
}

\author{
Olga Dečman Dobrnjič, $M S c$ \\ The National Education Institute of Slovenia \\ e-mail: olga.decman@zrss.si \\ Bojan Jeram, $B A$ \\ Society SPIRSA, Ljubljana, Slovenia \\ e-mail: bojan.jeram@guest.arnes.si
}

\begin{abstract}
A b stract
We were interested in how e-competent the parents as key partners of schools were. We carried out a research in which we checked the e-competence of parents of secondary school students in boarding schools, and their e-expectations for the boarding school. The study involved 492 parents of students who lived in large boarding schools in Slovenia and attended secondary school. The results indicate that parents use ICT and that they expect the boarding schools to have the possibility of collaboration with them via Internet. If boarding schools organized ICT related courses, the parents would be prepared to participate. The article discusses the role and the importance of information and communication technology (ICT) in school environment. We have found out that the process of informatisation has become one of the most important activities of the modern world, a generator of social success and a means of integrating with the developed world. For organizations that do not follow the global development of computerization, there is no future. Currently in the Slovenian school system the project e-Education is in progress. Its primary goal is to accelerate the process of informatisation of every educational institution, depending on its current status in management, educational and technical fields. The standards of an e-competent school, teacher (educator), headmaster and computer expert are being developed.
\end{abstract}

Key words: school environment, information, boarding school, e-competent parents, e-collaboration

\section{Foreword}

We are living in an age where information has become crucial in our daily life. When we need something, we go to the INTERNET and by means of INTERNET browsers we find it. In our business life too we are unable to do almost anything or go anywhere without it. (Trinh, 2010).

Influenced by the global informational society, Slovenia is getting actively involved in extended European educational environment which offers a continuously growing development and a number of professional challenges. The ICT (information 
and communication technology) together with its incorporation into the virtual environment is a condition for integrating into a globalized society.

The boarding schools in Slovenia are a part of the educational system and offer pupils additional secondary education. Their services are available to pupils of elementary schools as well as to college - university students and to special groups of children or pupils or students. They are organized in different organizational groups but they all depend upon the environment in which they live and work. (Dečman Dobrnjič 2007: 34 in Jeram 2010). There were 40 boarding schools in Slovenia in the school year 2010/2011 catering for 5,276 high school pupils and employing 203 tutors. The following chapters present the way in which these boarding schools are involved in informatisation.

\section{Global ICT environment}

The process of informatisation has become one of the most important activities of the modern world. The scientists call it a social - technological revolution. The consequences of such revolution have not yet been researched in depth. It is quite clear, however, that parallel to emerging of informational society radical changes will be introduced in all spheres of human activities. The information science and particularly its main tool the Internet is becoming a major industry of the future and the principal infrastructure of each society, the embodiment of development, the generator of social success and the means of integrating into developed world. The Internet, which today has more than a billion users, will soon be accessible to half of the world population (Soleša, 2007).

Nobody questions the importance of ICT (information and communication technology) and nobody doubts the significance of computers and the Internet which provide the communication in the globalized education.

In numerous countries, various ICT courses and other forms of education are available. Many schools and universities participate in this global e-universe through their Web sites. ICT competences are included as subjects and as objectives of all serious projects and objectives in the field of lifelong learning (Hinrich 2000).

Educational organizations are among the most important institutions of the global business operations. Their business processes therefore need to be brought closer to their environment by means of modern instruments. With this objective in view, the state has initiated the project called e-educational system. This project is being co-ordinated by the e-education centre and consists of three parts (Flogie, Harej, Razbornik and Podbršček, 2010):

- Development and implementation of counselling and support to e-competent schools (Project E-Support)

- Development and introduction of e-material and

- Development and realization of training of e-competent teachers (Project ECompetent Teachers). 
The basic objective of the Project E-Support is continuation and acceleration of the process of informatisation of each educational institution depending on its current conditions in terms of management, didactics and technical field. Teachers, tutors and headmasters are involved in the project. In terms of contents, the project establishes the foundations for work in three fields: counselling the school management (headmasters, development teams of the schools), didactic counselling and the system of technical assistance to educational institutions. Parallel to these processes the system of evaluation has been developed. In 2009 around 4,100 advisers' hours were carried out in various institutions of the system.

The project E-Educational System comprises the projects of setting the standards for the e-competent teacher, headmaster, school computer expert and the school. In this framework the training and other activities providing counselling to schools at various levels are prepared and conducted. Teachers, headmasters and other professionals are involved in the project and a closer cooperation with universities and other institutions dedicated to education from home and abroad is being introduced. In 2009 only, 879 seminars with 7,887 participants were carried out. A document Standard for an ECompetent Teacher, Headmaster and School Computer Expert was drawn up. The standard determines 6 basic skills for teachers, headmasters, school computer experts; the structure of obtaining the licence; the way how to comply with the standard and the requirements regarding renewal of the licence (Kreuh, Gruden and Čampelj, 2010).

\section{Informatisation of the school environment}

Somehow the Internet classrooms, the e-grades register, Internet communities, and e-teachers' room are the most easily recognized school environments. Until recently, the staff were opposed strongly to e-teachers' room which is becoming more and more the teaching staff's virtual centre. It is a place of exchanging information and communication among the professional staff. Its particular advantages are transparency, accessibility and usefulness. The access is unlimited in terms of time provided, however, that there is possibility of connecting to the Internet. The usefulness of access via the Internet is proved by the number of visitors. The e-room has significantly increased the amount of information made available to the staff, the transparency of work and activities in all units. An efficient time management and speedy flow of information are as important in educational institutions as in business companies (Zupančič, 2009).

It is our opinion that in order to work successfully with pupils, the e-connection between schools and parents is as important as the e-connection between teachers and between teachers and the management. We are living in an age when, due to their professional engagement, parents' absence from homes is becoming longer and longer. That is why we believe that it would be reasonable to strengthen the cooperation with parents by means of ICT. ICT itself cannot be a substitute for a genuine human encounter, but it can increase the minimum level of accessibility of information on the progress and work of their children (Vehar, Jerman, 2009: 74).

The tutors in boarding schools use various modes of cooperation with parents, whereby the availability of information seems to be the essence of relationships. ICT is gaining in importance and value in boarding schools, too. A research in this field proved 
that the conventional forms of cooperation between parents and teachers - tutors in boarding schools are more and more intertwined with modern forms and methods of work with parents (Dečman Dobrnjič, 2009).

\section{Boarding schools and environment communication - research}

Internet has transformed and globalised the operations to an unimagined extent. New media have turned up: home pages, electronic mail, internet relay chat or on-line chat, electronic notice boards, Internet seminars and so on. A new world system is emerging (Kotler and Caslione, 2009: 31).

The field of ICT is one of the most quickly developing businesses in the world and with the development of the technology the supply of the most diverse possibilities grows. Equally, the school environment is getting better equipped and ICT more accessible (Kač, 2008). Adequate ICT equipment in boarding schools is a requirement for informatisation of boarding schools and consequently for e-cooperation between parents and tutors.

\section{The purpose and the objectives of research, research method and sample}

The purpose of the research was to determine the e-competence of parents and their willingness to cooperate with the boarding school via Internet. To obtain the relevant data we conducted a survey and the instrument of the research was a questionnaire. The research sample comprised 492 pupils of boarding schools attending secondary education (high schools). The survey was carried out with tutors' assistance in nine boarding schools in the cities of Ljubljana, Maribor, Novo mesto and Ruše on 31st August, i.e. on the eve of the beginning of the school year when the children were brought by their parents to the boarding school.

For the purpose of the research the following hypotheses were put forward and tested by means of questionnaire responses:

- Hypothesis 1: Parents wish to cooperate with boarding schools via the Internet

- Hypothesis 2: Parents wish to participate in the Internet community of parents of boarding school pupils

- Hypothesis 3: Parents would participate in training in the field of ICT should the boarding school organize it.

The questionnaires were prepared in a conventional way on paper; the results however were processed by means of computer software. 
Analysis of questionnaire responses:

Note: $F=$ frequency (number of responses) - in all tables herein

\begin{tabular}{|l|c|c|}
\hline Do you have a computer at home? & F & $\%$ \\
\hline Yes & $\mathbf{4 8 1}$ & 97.76 \\
\hline No & $\mathbf{1 0}$ & 2.03 \\
\hline No reply & $\mathbf{1}$ & 0.20 \\
\hline
\end{tabular}

Table 1: Personal computer

Most parents (97.76\%) replied that they had a computer at home.

\begin{tabular}{|l|c|c|}
\hline Do you have Internet access at home? & F & $\%$ \\
\hline Yes & $\mathbf{4 6 3}$ & 94.11 \\
\hline No & $\mathbf{2 8}$ & 5.69 \\
\hline No reply & $\mathbf{1}$ & 0.20 \\
\hline
\end{tabular}

Table 2: Access to Internet

Most parents replied that they had Internet access at home

\begin{tabular}{|l|c|c|}
\hline $\begin{array}{l}\text { If you have Internet access at home, } \\
\text { which Internet connection do you use? }\end{array}$ & F & $\%$ \\
\hline Call connection via telephone modem & $\mathbf{7 6}$ & 15.45 \\
\hline ADSL access via telephone connection & $\mathbf{2 1 1}$ & 42.89 \\
\hline Cable connection & $\mathbf{1 0 2}$ & 20.73 \\
\hline Optical connection & $\mathbf{5 3}$ & 10.77 \\
\hline No reply & $\mathbf{5 0}$ & 10.16 \\
\hline
\end{tabular}

Table 3: Type of connection with Internet

The responses showed that the majority of respondents (74.29) had a broadband connection with Internet (ADSL, cable, optical cable) and only $15.43 \%$ still featured the connection through an ordinary telephone modem. 50 respondents gave no reply. 


\begin{tabular}{|l|c|c|}
\hline Do you use the Internet? & F & $\%$ \\
\hline Yes & $\mathbf{4 5 3}$ & 92.07 \\
\hline No & $\mathbf{3 7}$ & 7.52 \\
\hline No reply & $\mathbf{2}$ & 0.41 \\
\hline
\end{tabular}

Table 4: Use of the Internet

The majority of the parents covered by the survey (92.07\%) responded that they used the Internet.

\begin{tabular}{|l|c|c|}
\hline If yes, what purpose do you use the Internet for? & F & $\%$ \\
\hline To look for information on the Internet and to study it & $\mathbf{4 2 1}$ & 85.57 \\
\hline For communication by means of e-mailing & $\mathbf{3 2 9}$ & 66.87 \\
\hline To participate in discussions (forums) & $\mathbf{6 6}$ & 13.41 \\
\hline To participate in social networks (Facebook, Twitter, ...) & $\mathbf{1 7 1}$ & 34.76 \\
\hline Others & $\mathbf{2 9}$ & 5.89 \\
\hline$-9-11$ & \\
Banking, bill payments & 8 & \\
For professional purposes & 3 & \\
Shopping & 2 & \\
Education & 1 & \\
Reading newspapers & 1 & \\
Taxes & 1 & \\
e-agriculture & $\mathbf{4 5}$ & 9.15 \\
\hline No reply & & \\
\hline
\end{tabular}

Table 5: The purpose of using the Internet

\begin{tabular}{|l|c|}
\hline If no, what are the reasons for not using it? & F \\
\hline We do not have access to the Internet network & 9 \\
\hline I do not need it & 5 \\
\hline I do not know how to use a computer & 3 \\
\hline I do not know how to use the Internet & 2 \\
\hline We do not have a computer & 1 \\
\hline I am not interested in it & 1 \\
\hline I do not want it & 1 \\
\hline We get all the information from the radio and television & 1 \\
\hline My daughter looks up everything I need & 1 \\
\hline
\end{tabular}

Table 6: Reasons for not using the Internet

From the replies we found out that the majority of the parents used the Internet to look for and to read information, to communicate by means of e-mailing and to 
participate in social networking and in discussions in forums. Quite a few parents used Internet for other purposes.

The reasons of those parents who did not use the Internet were diverse, but most often they simply did not have the network available or they did not know how to use a computer.

\begin{tabular}{|l|c|c|}
\hline $\begin{array}{l}\text { Have you visited the Web site of your child's } \\
\text { boarding school? }\end{array}$ & $\mathrm{F}$ & $\%$ \\
\hline Yes & $\mathbf{3 7 2}$ & 75.61 \\
\hline No & $\mathbf{1 1 9}$ & 24.19 \\
\hline No reply & $\mathbf{1}$ & 0.20 \\
\hline
\end{tabular}

Table 7: WEB site of your child's boarding school

We discovered that the majority of parents $(75.61 \%)$ had visited their child's boarding school WEB site.

\begin{tabular}{|l|c|c|}
\hline $\begin{array}{l}\text { Do you know the contents of the Web site of your } \\
\text { child's boarding school? }\end{array}$ & F & $\%$ \\
\hline Yes & $\mathbf{2 5 6}$ & 52,03 \\
\hline No & $\mathbf{2 1 9}$ & 44,51 \\
\hline No reply & $\mathbf{1 7}$ & 3,46 \\
\hline
\end{tabular}

Table 8: The contents of the boarding school WEB site

More than half of the parents replied, that they knew the contents of the WEB site of their child's boarding school.

\begin{tabular}{|l|c|}
\hline $\begin{array}{l}\text { Which part of the contents of the boarding school Web site are } \\
\text { most interesting to you? }\end{array}$ & F \\
\hline $\begin{array}{l}\text { General information on boarding school, presentation, rules of the } \\
\text { house, safety regulations }\end{array}$ & 60 \\
\hline Photo gallery & 40 \\
\hline How to use free time, leisure and sports activities & 35 \\
\hline Social events in the boarding school, activities and events & 31 \\
\hline Menus & 29 \\
\hline News and notices & 29 \\
\hline All & 29 \\
\hline Inscription in the boarding school & 6 \\
\hline Presentation of the education groups, group life & 3 \\
\hline Pupils' pages & 2 \\
\hline History & 1 \\
\hline
\end{tabular}

Table 9: What is most interesting on the WEB site of your child's boarding school? 
The fact that parents found information topics like photo galleries, data on leisure and sports activities, on social events and menus in the contents of WEB sites most interesting, leads us to the conclusion that they followed up what was going on in the boarding schools.

\begin{tabular}{|l|c|}
\hline $\begin{array}{l}\text { Do you miss any contents on Web sites that would be of interest } \\
\text { to you? }\end{array}$ & F \\
\hline I do not miss anything & 79 \\
\hline Updated information on events & 4 \\
\hline Updated photo-gallery, actual photo news & 3 \\
\hline Menu & 2 \\
\hline Photos of the rooms & 1 \\
\hline E-mail communication with tutors & 1 \\
\hline Information on the parents' meetings schedule & 1 \\
\hline Parents' questions and answers on them & 1 \\
\hline Arrangement of groups at the beginning of school year & 1 \\
\hline Timetable of the city buses & 1 \\
\hline $\begin{array}{l}\text { More statements of the pupils on life in boarding schools (truthful } \\
\text { and objective) }\end{array}$ & 1 \\
\hline
\end{tabular}

Table 10: Which contents on boarding schools WEB sites are missing?

The data in table 10, which told us what the parents missed on the boarding schools WEB sites, may represent a direction for the tutors and for the headmaster as to what contents are still wanted and should be put on the WEB sites.

\begin{tabular}{|l|c|c|}
\hline Are the Web sites updated regularly? & F & $\%$ \\
\hline Yes & $\mathbf{2 2 0}$ & 44.72 \\
\hline No & $\mathbf{1 4}$ & 2.85 \\
\hline No reply & $\mathbf{2 5 8}$ & 52.44 \\
\hline
\end{tabular}

Table 11: How updated are the Web sites of boarding schools?

Most respondents thought that the information on the boarding schools Web sites was updated enough. 


\begin{tabular}{|l|c|c|}
\hline $\begin{array}{l}\text { Beside personal contacts and telephone conversations, } \\
\text { would you like to cooperate with boarding schools by } \\
\text { means of modern information communication } \\
\text { technology (Internet)? }\end{array}$ & F & $\%$ \\
\hline Yes & $\mathbf{3 2 3}$ & 65.65 \\
\hline No & $\mathbf{1 4 7}$ & 29.88 \\
\hline No reply & $\mathbf{2 2}$ & 4.47 \\
\hline
\end{tabular}

Table 12: Cooperating by means of the Internet

The replies revealed that many parents $(65.65 \%)$ wished to cooperate with the boarding schools by means of the Internet.

\begin{tabular}{|l|c|c|}
\hline $\begin{array}{l}\text { Specify how you would like to cooperate with } \\
\text { boarding schools via the Internet? }\end{array}$ & F & $\%$ \\
\hline $\begin{array}{l}\text { Receiving information on events in boarding school } \\
\text { through boarding school Web site }\end{array}$ & $\mathbf{2 6 2}$ & 53.25 \\
\hline Communicating with boarding school (tutor) via e-mail & $\mathbf{2 7 2}$ & 55.28 \\
\hline Participating in Internet community of parents & $\mathbf{7 9}$ & 16.05 \\
\hline Others & $\mathbf{1 3}$ & 2.64 \\
\hline$-\begin{array}{c}\text { By phone } \\
\text { Personally }\end{array}$ & 7 & \\
\hline No reply & $\mathbf{1 1 6}$ & 23.58 \\
\hline
\end{tabular}

Table13: Possibility of cooperating via the Internet

The responses led us to the conclusion that the majority of parents wished to communicate with boarding schools via e-mail (55.28\%) and 53.25\% wished to be informed on events in boarding schools via the boarding school web-site. $16.05 \%$ of the persons covered by the survey said that they would like to participate in the Internet parents' community. It came as a surprise that only 4 parents replied that they wanted to cooperate with the boarding school personally only.

\begin{tabular}{|l|c|c|}
\hline $\begin{array}{l}\text { Would you participate in training courses if the boarding } \\
\text { school organized them for the purpose of promoting the } \\
\text { parents' cooperation with the boarding school using the } \\
\text { Internet? }\end{array}$ & F & $\%$ \\
\hline Yes, I would attend such training & $\mathbf{1 0 9}$ & 22.15 \\
\hline Yes, I would attend such training if it was free of charge & $\mathbf{9 1}$ & 18.50 \\
\hline No, I am not interested in such training & $\mathbf{2 0 6}$ & 41.87 \\
\hline No reply & $\mathbf{8 6}$ & 17.48 \\
\hline
\end{tabular}

Table 14: Parents' attending the training 
The responses led us to the conclusion that roughly half of the parents (40.65\%) who replied to the question expressed their readiness to participate in training courses organised by boarding schools.

\begin{tabular}{|l|c|c|}
\hline $\begin{array}{l}\text { Which of the said training courses would be } \\
\text { interesting to you? }\end{array}$ & F & $\%$ \\
\hline Use of the Internet & $\mathbf{8 5}$ & 17.27 \\
\hline Communicating by e-mail & $\mathbf{8 9}$ & 18.09 \\
\hline Participating in Internet parents' community & $\mathbf{9 5}$ & 19.31 \\
\hline No reply & $\mathbf{2 8 9}$ & 58.74 \\
\hline
\end{tabular}

Table 15: Training courses that were interesting to parents

Most of the parents involved in the survey were interested in training on participating in the Internet community of parents, followed by communicating by means of e- mail and courses on using the Internet.

\section{Testing of hypotheses}

The hypotheses were tested by considering the responses from the questionnaires.

The first hypothesis that parents wish to cooperate with boarding schools via the Internet can be accepted as this was the reply of most of the parents. They would cooperate with boarding schools via boarding school Web site, e-mail and Internet communities.

We accept the second hypothesis that parents would participate in internet community of boarding schools as $16.05 \%$ of all surveyed parents replied affirmatively and also expressed their wish to participate in training for participating in parents' Internet community $(19.31 \%)$.

We accept the third hypothesis that parents would participate in organized training in boarding schools in the field of ICT; $40.65 \%$ of parents covered by the survey wished to participate in training and less than a half only in case the training was free of charge.

\section{Conclusion}

Should schools and boarding schools wish to meet the needs of the pupils and their parents, they would have to include informatisation in their business operations. Presently the most recognized e-school environments are e-grades registers, internet communities and e-teachers' rooms. In our opinion, it is indispensable to develop ecommunication between schools and parents to assure their successful work. We have found out that the information and communication technology has become part of communication in all environments. Slovenian education policy is well aware of this fact. For this purpose a national project e-educational system covering educational 
institutions, headmasters, teachers, tutors, and computer science professionals is being carried out.

The research conducted among 492 secondary school pupils staying at boarding schools has shown that the vast majority of parents use the Internet to look up and read data, that they communicated via e-mail and social networks and discussions in forums. Most of the parents are familiar with the Web site of their child's boarding school, which in turn proves how important an element for the image of a boarding school the Web site is.

From the responses we have concluded that a lot of parents wish to cooperate with boarding schools via the Internet, they further wish to be informed about the events in boarding school through the boarding school Web sites and finally they wish to participate in parents' communities by means of e-mailing. We were rather surprised to find out that as many as half of the parents would participate in organized training in boarding schools if it were possible considering their other engagements. Most parents are interested in training on joining Internet community of parents, communicating via e-mails and in training on how to use Internet. That is why we propose to the administration of e-education to include pupils' parents as the most important external partners in the educational environment.

\section{References and sources}

1. Dečman Dobrnjič, O. (2007): Politika razvoja dijaških domov. Magistrsko delo, Fakulteta za managament, Koper.

2. Dečman Dobrnjič, O. (2009): Uvajanje IKT in sodelovanje s starši. Mednarodna konferenca Splet izobraževanja in raziskovanja z IKT - SIRIKT 2009, Kranjska Gora, Ljubljana: Arnes, 2009.

3. Dečman Dobrnjič, O., Cavnik, B., Badoko, B., Vidak, M., Tehovnik, F. (2010): E-šolstvo in e-kompetence v dijaških domovih - raziskava. Iskanja (Celje), leto 28, št. 37-38, str. 25-33.

4. Flogie, A., Harej J., Razbornik I., Podbršček I. (2010): Razvoj in izvedba svetovanja ter podpore e-kompetentnim šolam. V: Mednarodna konferenca Splet izobraževanja in raziskovanja z IKT - SIRIKT 2010 Kranjska gora. Ljubljana: Arnes.

5. Hinrich R. (2000): A Vision for Life Long Learning -Year 2020. Introduction by Bill Gates. Learning Science and Technology. Microsoft Research. Microsoft.

6. Jeram, B. (2010): Pedagoški delavci in IKT komunikacija. Iskanja (Celje), leto 28, št. 37 38, str. 25-33.

7. Kač, L. (2008): Svet mladih - svet medijev. Kaj pa šola? Vzgoja in izobraževanje št. 5. Zavod R Slovenije za šolstvo, Ljubljana. str. 45.

8. Kotler P., J.A. Caslione. (2009): Kaotika: Upravljanje in trženje v obdobju pretresov. Ljubljana, GV Založba.

9. Kreuh, N., Gruden,B., Čampelj B. (2010): Na poti k e-kompetentni šoli. V: Mednarodna konferenca Splet izobraževanja in raziskovanja z IKT - SIRIKT 2010 Kranjska gora. Ljubljana: Arnes.

10. Soleša, D. (2007): Informacione tehnologije. Pedagoška fakulteta v Somboru. Novi Sad.

11. Trinh K. (2010): Preoblikovanje izobraževanja v 21. stoletju. V: Mednarodna konferenca Splet izobraževanja in raziskovanja z IKT- SIRIKT 2010 Kranjska gora. Ljubljana: Arnes. 
12. Vehar Jerman, A. (2009): IKT - most med šolo in starši. V: Zbornik 12. mednarodne multikonference. Informacijska družba IS 2009. Ljubljana: Ministrstvo za šolstvo in šport, Univerza v Mariboru, fakulteta za organizacijske vede, Inštitut Jožef Štefan in Zavod Republike Slovenije za šolstvo.

13. Zupančič, J. (2009): E-zbornica. Mednarodna konferenca Splet izobraževanja in raziskovanja z IKT - SIRIKT 2009, Kranjska Gora, Ljubljana: Arnes, 2009.

Metodički obzori 6(2011)2

Prethodno priopćenje

UDK: 37.018.3:004](497.4)

Primljeno: 27. 12. 2010.

\title{
KAJ E-KOMPETENTNI STARŠI PRIČAKUJEJO OD DIJAŠKEGA DOMA?
}

\author{
mag. Olga Dečman Dobrnjič \\ The National Education Institute of Slovenia \\ e-mail: olga.decman@zrss.si \\ Bojan Jeram, BA \\ Society SPIRSA, Ljubljana (Slovenia) \\ e-mail: bojan.jeram@guest.arnes.si
}

\begin{abstract}
Povzetek
Sprašujemo se, kako je z e-kompetentnostjo staršev kot najpomembnejših partnerjev šole. V ta namen smo naredili raziskavo, s katero smo preverili ekompetentnost staršev dijakov dijaških domov ter njihova e-pričakovanja do dijaškega doma. $\mathrm{V}$ raziskavi je sodelovalo 492 staršev dijakov, ki bivajo $\mathrm{v}$ dijaških domovih $\mathrm{v}$ Sloveniji in obiskujejo sekundarno izobraževanje. Rezultati raziskave kažejo, da starši uporabljajo IKT in da od dijaškega doma pričakujejo možnost sodelovanja preko interneta. $\mathrm{V}$ primeru, da bi dijaški dom izobraževanje s področja IKT organiziral, so se pripravljeni tudi izobraževati. V članku govorimo tudi o vlogi in pomenu informacijsko-komunikacijske tehnologije (IKT) v šolskem okolju. Ugotavljamo, da je proces informatizacije postal ena od najvažnejših aktivnosti sodobnega sveta, generator družbenega uspeha in sredstvo za povezovanje z razvitim svetom. Za organizacije, ki ne bodo sledile globalnemu razvoju informatizacije, ni prihodnosti. V šolskem sistemu se na nacionalnem nivoju dogaja projekt e-šolstvo. Osnovni cilj projekta je pospešitev procesa informatizacije vsakega vzgojno izobraževalnega zavoda $\mathrm{v}$ odvisnosti od njegovega trenutnega stanja na vodstvenem, didaktičnem in tehničnem področju. Razvija se standard e-kompetentne šole, učitelja, vzgojitelja, ravnatelja, računalničarja.

Ključne besede: šolsko okolje, informacije, dijaški dom, e-kompetentni starši, e-sodelovanje
\end{abstract}

